\title{
Market Incentives and Regulators' Activity Shaping Financial Information: An Analysis of the Net Debt Disclosure in Italy
}

\author{
M. Pizzo ${ }^{1}$, N. Moscariello ${ }^{1} \&$ R. Vinciguerra ${ }^{1}$ \\ ${ }^{1}$ Dept. of Economics, University of Naples II, Italy \\ Correspondence: N. Moscariello, Dept. of Economics, University of Naples II, Italy. E-mail: \\ nicola.moscariello@unina2.it \\ Received: February 8, 2014 \\ Accepted: October 22, 2014 \\ Online Published: December 20, 2014 \\ doi:10.5539/ijbm.v10n1p1 \\ URL: http://dx.doi.org/10.5539/ijbm.v10n1p1
}

\begin{abstract}
As a performance indicator, net debt conveys information to assess firms' gearing level and the ability to service the outstanding borrowings. Moreover, net debt is frequently used in debt covenants in order to reduce information asymmetry between borrowers and lenders and to enhance the efficiency of the debt contracting process.

Notwithstanding the decision usefulness and the contracting relevance associated to net debt disclosure, contrasting positions have been suggested concerning the notion of- and the information about the net financial position. In particular, a regulated/narrow approach contrasts an unregulated/principle-based one, and both the academic literature and accounting profession are far from being unanimous on this issue.

By examining financial statements of 60 Italian listed companies, we compare the content of the net debt disclosure produced in a non-regulated environment with that delivered within a mandatory disclosure regime. Our analysis shows that the adoption of a mandatory disclosure regime has only slightly enhanced the comparability of net debt disclosure and highlights the opportunistic nature of the disclosure about the net financial position. At the same time, the multivariate analysis shows the role that regulation could play as a low-cost commitment device.
\end{abstract}

Keywords: net financial position, net debt disclosure, financial information quality, mandatory disclosure

\section{Introduction}

In accordance to the unraveling arguments, market forces can lead to optimal corporate disclosure level (Grossman \& Hart, 1980; Grossman, 1981; Milgrom, 1981; Leuz \& Wysocki, 2008). In fact, several papers predict a negative relation between high quality voluntary disclosure and the firms' cost of capital. Moreover, empirical studies reveal that such a theoretical framework applies to both equity and debt capital (Diamond \& Verrecchia, 1991; Kim \& Verrecchia, 1994; Lambert et al., 2007; Botosan, 1997; Leuz \& Verrecchia, 2000; Sengupta, 1998).

Notwithstanding the strength of the voluntary disclosure hypothesis, several reasons also support a mandatory disclosure regime (Cooper \& Keim, 1983; Leuz \& Wysocki, 2008).

First, the non-intervention approach assumes that outside investors know that firms possess private information and, consequently, price the securities according to the companies' disclosure quality. However, the free-rider problem due to the high costs for gathering and evaluating financial data could prevent capital providers from deeply examining financial disclosure (Gonedes \& Dopouch, 1974; May \& Sundem, 1976; Gordon, 1989). Second, as a public good, corporate disclosure creates several externalities. In this case, a disclosure regulation could mitigate the costs associated to an under-or overproduction of information by mandating the socially optimal level of financial information (Coffee, 1984). Third, because of the contractual incompleteness characterizing corporate contracts, a mandatory regime might represent a low-cost commitment device and a more efficient instrument than the private negotiation to alleviate the moral hazard problem (Mahoney, 1995; Rock, 2002).

Indeed, with regard to the debt contracting process, important evidence have been collected concerning accrual or financial leverage manipulations in order to avoid debt covenants violation (Abdel-khalik, 1981; Sweeney, 1994; Godfrey \& Warren, 1995; Engel et al., 1999; Beattie et al., 2000; Dichev \& Skinner, 2002). 
These papers analyze earnings and balance sheet manipulations and describe the role that the accounting standards play to manage the "moral hazard" issue that affect the effectiveness and the efficiency of debt contracts. We follow this research stream and analyze the notes to the financial statements, assessing a possible relation between the quality of firms' net indebtedness disclosure and the credit risk profile.

In particular, we examine the Italian listed companies' net debt disclosure. We assess a possible misuse of the information about the net financial position and analyze the role that a regulatory intervention can play to tackle the moral hazard issue.

Indeed, important reasons justify our choice of analyzing the net debt disclosure into the Italian setting.

In fact, contrasting positions have been suggested concerning the definition of net debt and the disclosure about the net financial position, and the academic literature and the accounting profession are far from being unanimous on this issue. However, notwithstanding the uncertainty pervading the notion of- and the information about the net debt, since the 2006 the Italian Stock Exchange Commission (CO.N.SO.B.) requires the Italian listed companies to produce a standardized disclosure about their indebtedness in the notes to financial statements. Therefore, the CO.N.SO.B. intervention has made the Italian setting an ideal one for: 1) comparing the content of the net debt disclosure produced in a non-regulated environment with that delivered within a mandatory disclosure regime; 2) assessing the ability of regulators' activity to prevent managers from offering a biased picture of their entity's liquidity and solvency positions; and 3) evaluating the possibility that a mandatory disclosure on net debt might serve as a low-cost commitment device enhancing the efficiency in debt contracting processes.

This paper continues as follows: the second section analyzes the notion of net debt in the accounting literature and the information required by the accounting standards. The third section develops an empirical analysis in order to describe the information about the net financial position and to detect factors affecting companies' choice to comply with CO.N.SO.B. net debt disclosure scheme. The fourth section concludes.

\section{The Net Debt in the Accounting Literature and Standards}

\subsection{The Notion of Net Debt}

Net Debt can be roughly defined as "financial liabilities that an entity classifies in the financing section together with the resources available to service those financial liabilities" (IASB, 2010, p. 4).

Although the net debt represents a key indicator of a company financial performance by offering a synthetic picture of a firm's credit standing, scholars and standard setters have paid a weak attention on this topic. For this reason, a common definition of net debt is still lacking and any attempt to impose a specific configuration risks to be arbitrary and subjective (IASB, 2010).

Some scholars identify the net financial position with the difference between current financial assets and short-term and long-term financial liabilities (Elliot \& Elliot, 1997; Palepu and Healy, 2008; Vernimmen et al., 2011; Damodaran, 2012).

By considering only current financial assets as a resource available to service both short-term and long-term financial liabilities, such a computational scheme decreases the probability of an underestimation of the insolvency risk (conservative approach); however, it also offers an inconsistent picture of the net financial position, as it does not seek for a temporal and functional homogeneity in the items involved.

It is therefore common to calculate the net financial position by adding to the Net Current Financial Indebtedness (short-term financial liabilities plus liquidity and current receivables) the difference between long-term financial liabilities and non-current financial assets (Penman, 2007; Subramanyam, Wild, 2009; Teodori, 2009; Pizzo, 2010; Bhattacharyya, 2011). This scheme mitigates the temporal asymmetry characterizing the previous configuration, but introduces high risky positive components (long-term financial assets) that negatively affect the reliability of the performance indicator.

Standard setters also present contrasting opinions concerning the net debt disclosure. In fact, at least two different approaches regarding the net debt definition issue emerge from a brief analysis of the financial reporting standards dealing with this topic (FAF \& IASCF, 2009).

A narrow definition - which prescribe a specific set of assets and liabilities to be included as part of net debt - is adopted, for example, by the UK Accounting Standards Board. In this case, net debt is strictly defined as "the borrowings of the reporting entity less cash and liquid resources" (FRS 1, paragraph 2, 1996). Similarly, a standardized definition of the net debt is proposed by the CESR (Committee of the European Securities Regulators) Recommendation (2005) (Note 1) and the EFRAG Paper (2011) (Note 2). 
Such an approach clearly aims to achieve a consistent measure of net debt from entity to entity. However, the theoretical and practical difficulties associated to an unambiguous identification of the liabilities/assets correlated to the entity's financing activities significantly threaten the usefulness of this performance indicator. Moreover, accounting boards and regulators supporting a narrow definition of the net debt systematically propose a conservative view of the performance indicator, although - as discussed above - the accounting literature is still debating on the usefulness of such a computational scheme.

In alternative, a principle-based definition is proposed by the IASB/FASB joint Staff Draft (2010) (Note 3). The IASB/FASB Draft Paper reminds the impossibility to have a common and rigorous definition of Net Debt and, consequently, gives to the entity a full flexibility to define the components of Net Debt. The entity is allowed to determine which items it manages as debt and the resources available to service those debts.

On the one hand, the non-regulated nature of a principle-based definition intends to give to the insiders of the firm the opportunity to deliver private information useful for a better assessment of their company's prospects. On the other hand, the lack of standardization reduce financial statements' comparability and might also permit managers/controlling shareholders to undertake opportunistic behavior to the detriment of minorities and creditors.

\subsection{The information about Net Debt}

The information required by Standard Boards and Regulators about the firms' gearing level is clearly influenced by the notion of Net Debt they support. In fact, those proposing a narrow/regulated approach hypothesize a more rigid disclosure about net debt compared to the Committees indicating a principle-based/non-regulated one.

For example, the UK Standard Board requires two separate pieces of information in order to enable the movements in net debt to be readily understood: a) net debt reconciliation below the statement of cash flows, and b) an analysis of the performance indicator in the notes to financial statement (FRS 1, par. 33, 1996).

A reconciliation of movements in cash with movements in net debt aims to offer a broader basis to assess an entity's liquidity, solvency and financial flexibility (Table 1a). Indeed, a detailed reconciliation of the net debt position to the statement of cash flows should ensure that users' assessment of net cash flow is not distorted by transactions that are deemed to be value neutral to shareholders (such as redemptions or issuance of debt or purchase of money market funds) (CRUF, 2009). At the same time, an analysis of net debt in the notes to financial statement identifies individual components of net debt that might not be apparent in the statement of financial position (Table 1b).

Table 1a. FRS 1-reconciliation of movements in cash with movements in net debt

\begin{tabular}{l} 
Increase or decrease in cash (as shown in the bottom of the statement of cash flows) \\
Add back (+/-) \\
Cash flows from decrease/increase relating to liquid resources and to borrowings \\
\hline Movement in net debt resulting from cash flows \\
Add \\
Other changes in net debt that do not arise from cash flows (non-cash items) \\
- Loans and finance leases acquired in subsidiary undertakings \\
- Provisions \\
- Exchange differences \\
Movement in net funds (debt) in the year \\
Net funds (debt) at the beginning of the period \\
Net funds (debt) at the end of the period \\
\hline
\end{tabular}


Table 1b. FRS 1-analysis of net debt

\begin{tabular}{lcccccc}
\hline & $\begin{array}{c}\text { Opening } \\
\text { Balance }\end{array}$ & Cash flow & Acquisition & $\begin{array}{c}\text { Other non } \\
\text { cash changes }\end{array}$ & $\begin{array}{c}\text { Foreign } \\
\text { Exchange } \\
\text { Movements }\end{array}$ & $\begin{array}{c}\text { Ending } \\
\text { Balance }\end{array}$ \\
\hline Cash & $\mathrm{X}$ & $\mathrm{X}$ & --- & --- & $\mathrm{X}$ & $\mathrm{X}$ \\
Deposits & $\mathrm{X}$ & $\mathrm{X}$ & --- & --- & --- & $\mathrm{X}$ \\
Overdrafts & $\mathrm{X}$ & $\mathrm{X}$ & --- & --- & $\mathrm{X}$ & $\mathrm{X}$ \\
Short-term debt & $\mathrm{X}$ & $\mathrm{X}$ & --- & $\mathrm{X}$ & $\mathrm{X}$ & $\mathrm{X}$ \\
Long-term debt & $\mathrm{X}$ & --- & --- & $\mathrm{X}$ & $\mathrm{X}$ & $\mathrm{X}$ \\
Finance lease & $\mathrm{X}$ & $\mathrm{X}$ & $\mathrm{X}$ & --- & $\mathrm{X}$ & $\mathrm{X}$ \\
Current asset investments & $\mathrm{X}$ & $\mathrm{X}$ & --- & --- & --- & $\mathrm{X}$ \\
\hline Total & $\mathrm{X}$ & $\mathrm{X}$ & $\mathrm{X}$ & $\mathrm{X}$ & $\mathrm{X}$ & $\mathrm{X}$ \\
\hline
\end{tabular}

Information about the net debt also plays an important role according to the EFRAG. In the wake of the view expressed by many European constituents (mainly in UK and France), the EFRAG has recently issued a discussion paper that supports the hypothesis to align the definition of the balance sheet financing section with the notion of net debt. According to the European group, the presentation of net debt in the balance sheet through the inclusion of cash and short-term financial investments among an entity's financial liabilities would better inform the users as to how the financial position is being managed (EFRAG, par. 33.b, 2010).

Finally, the CESR suggests a detailed disclosure in the notes to financial statements, requiring both a short term (cash and cash equivalents plus current financial debts) and a medium-long term (net current financial indebtedness plus non-current financial indebtedness) disclosure about the net financial position (CESR, par. 3.2, 2005) (Table 2).

Table 2. CESR net debt disclosure scheme

\begin{tabular}{|c|c|}
\hline \multicolumn{2}{|l|}{$\begin{array}{l}\text { A. Cash } \\
\text { B. Cash equivalent (Detail) } \\
\text { C. Trading Securities }\end{array}$} \\
\hline E. Current Financial Receivable .................................. & $\boldsymbol{X}$ \\
\hline $\begin{array}{l}\text { F. Current Bank debt } \\
\text { G. Current portion of non current debt } \\
\text { H. Other current financial debt } \\
\text { I. Current Financial Debt }(\mathbf{F})+(\mathbf{G})+(\mathbf{H}) \ldots \ldots \ldots \ldots \ldots \ldots \ldots \ldots \ldots\end{array}$ & $\boldsymbol{X} \boldsymbol{X} \boldsymbol{X}$ \\
\hline $\begin{array}{l}\text { J. Net Current Financial Indebtedness (I) - (E) - (D) ...... } \\
\text { K. Non current Bank loans } \\
\text { L. Bonds Issued } \\
\text { M. Other non current loans }\end{array}$ & $x \boldsymbol{X} x$ \\
\hline $\begin{array}{l}\text { N. Non current Financial Indebtedness }(\mathrm{K})+(\mathrm{L})+(\mathrm{M}) \text {.. } \\
\text { o. Net Financial Indebtedness }(\mathrm{J})+(\mathrm{N}) \ldots \ldots \ldots \ldots \ldots \ldots \ldots . .\end{array}$ & $\begin{array}{r}X X X \\
X X\end{array}$ \\
\hline
\end{tabular}

According to the CESR's Recommendation, issuers should be provide disclosure of Net Indebtedness in the short term and in the medium-long term. Disclosure of indirect and contingent indebtedness shall also be provided in a separate paragraph. Issuers should indicate the amounts and analyze the nature of Indirect Indebtedness and Contingent Indebtedness.

In contrast with the above mentioned positions, the IASB/FASB joint Staff Draft does not require a separate disclosure about net debt. However, while the FASB explicitly discourages any disclosure of net debt (Note 4), the IASB asserts that in any case information about net debt should be apparent in the financial statement. Consequently, the IASB suggests an analysis of the changes in balances of the line items that usually constitute a firm's net indebtedness (cash, short-term investments, debt categories and finance leases) to be summarized in a single note (Table n. 3). This information would represent an important guide for financial statements analysts and users, without preventing them from setting-up their own performance indicator. Therefore, it is possible to assert that the IASB now requires some form of net debt analysis, although it does not formally name it as such. Yet, the lack of an explicit definition of net debt does not eliminate the risk that entities will present net debt analyses differently as some entities will disclose, in addition to the required information, the changes in the other components of net debt as defined by the entity (KPMG, 2010). 
Table 3. IASB net indebtedness information

\begin{tabular}{|c|c|c|c|}
\hline \multicolumn{4}{|l|}{ Note $X$ - Debt } \\
\hline & Long-Term & Shor-Term & Interest \\
\hline Beginning balance 1 January & $X X$ & $X X$ & $X X$ \\
\hline Changes due to cash & $x$ & $x$ & $x$ \\
\hline \multicolumn{4}{|l|}{ Cash received from issuance of debt } \\
\hline \multicolumn{4}{|l|}{ Cash paid for interest } \\
\hline Total Changes due to cash & 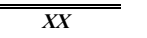 & $\overline{X X}$ & $\overline{X X X}$ \\
\hline Changes due to non-cash & $x$ & $x$ & $x$ \\
\hline \multirow{2}{*}{\multicolumn{4}{|c|}{$\begin{array}{l}\text { Loans acquired with subsidiary undertakings } \\
\text { Accrual - Interest }\end{array}$}} \\
\hline & & & \\
\hline \multicolumn{4}{|l|}{ Remeasurement - foreign exchange } \\
\hline Total Changes due to non-cash & 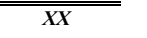 & 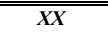 & $\overline{X X}$ \\
\hline Ending Balance 31 December & $X X$ & $X X$ & $X X$ \\
\hline \multicolumn{4}{|l|}{ Note $Y$ - Investments } \\
\hline & AFS Securities & & $\begin{array}{c}\text { Interest-bearing } \\
\text { deposits }\end{array}$ \\
\hline Beginning balance 1 January & $Y Y$ & & $Y Y$ \\
\hline Changes due to cash & $y$ & & $y$ \\
\hline \multicolumn{4}{|l|}{ Cash received from term deposits } \\
\hline \multicolumn{4}{|l|}{ Sale of Securities } \\
\hline Total Changes due to cash & $\overline{Y Y Y}$ & & $\overline{Y Y Y}$ \\
\hline Changes due to non-cash & $y$ & & $y$ \\
\hline \multicolumn{4}{|l|}{ Accrual - gain on sale of securities } \\
\hline \multicolumn{4}{|l|}{ Remeasurement - foreign exchange } \\
\hline \multicolumn{4}{|l|}{ Remeasurement - fair value } \\
\hline Total Changes due to non-cash & $\overline{Y Y Y}$ & & $\overline{Y Y Y}$ \\
\hline Ending Balance 31 December & YY & & YY \\
\hline
\end{tabular}

According to IASB/FASB Staff Draft, an entity would be required to analyze the changes in the balances of line items that normally constitute net debt (all items in the debt category, any short-term investments, and finance leases). However, that information would not need to be presented together in the notes as it is not possible to have a common definition of net debt.

Notwithstanding the above documented uncertainty pervading the notion of- and the information about Net Debt, in 2006 the Italian Stock Exchange Commission has ratified the CESR Recommendation, requiring the listed companies to deliver a standardized disclosure about their net financial position in the notes to financial statements. However, as the previous review showed, both the accounting literature and the standard setters do not fully support the CESR net debt configuration and strong empirical evidence concerning the usefulness of net debt disclosure still lack.

For this reason, the next section presents an empirical examination of the Net Debt disclosure delivered by the Italian listed companies. The aim of the research is to examine information about the net financial position in an unregulated environment (year 2005) and to assess the impact on the net debt disclosure quality during the mandatory regime since 2006. Then, a multivariate regression model is developed to investigate the determinants of firms' choice to comply with CESR/CO.N.SO.B. scheme.

\section{An Empirical Analysis}

\subsection{Sample Selection and Descriptive Statistics}

A sample of 60 companies has been randomly drawn from the total number of firms listed at the Milan Stock Exchange, after excluding for:

a) companies subject to foreign law;

b) companies with stock trading suspended; and

c) banks, insurances companies and financial services firms.

The number of the selected companies equals the $20.27 \%$ of the whole population $(43.16 \%$ in terms of market capitalization) and the $25.75 \%$ of the listed companies not belonging to the excluded categories $(67.80 \%$ in terms of market capitalization). 
For any of the selected firms, we examine the consolidated financial statements published during the period 2005-2008. We collect information about net indebtedness in order to analyze the voluntary disclosure on net debt delivered in 2005 and the compliance degree with respect to the CESR/CO.N.SO.B. requirements during the 2006-2008 periods.

At the end of the 2005 fiscal year, the $22 \%$ of our sample communicates no information about net indebtedness. Furthermore, none of the firms delivering information about their net financial position states to adopt the CESR Recommendation on a voluntary basis. Thus, the degree of comparability and understandability of the net debt information is extremely poor.

The $4.2 \%$ of the firms producing some disclosure about net debt adopts a Net Current Financial Indebtedness configuration (short-term financial liabilities plus liquidity and current receivables). At the same time, firms extending their disclosure to the medium-long term financial items show a different degree of conservatism in their financial information. In fact, the $47 \%$ of this sub-sample adds to the long-term liabilities the total amount of non-current financial assets.

Finally, a high heterogeneity also characterizes the documents selected to convey net debt disclosure. The $69.5 \%$ of the firms communicates their indebtedness through the Management's Discussion \& Analysis; the $17.5 \%$ uses the notes to financial statements to deliver this information, while the $13 \%$ includes a scheme on Net Debt in both documents.

An analysis of the 2006-2008 financial statements highlights the impact of the CESR/CO.N.SO.B. rule on the Italian listed companies' disclosure. As a result of such a regulatory intervention, a higher number of firms communicate their net indebtedness and a greater homogeneity regarding the document used to provide information about the net financial position can also be observed. Indeed, only 2 over 60 firms fail to produce a net debt disclosure during the first year of applicability of the new rule, and more than the $80 \%$ of the observed firms convey the net debt disclosure through the notes to financial statements.

Nevertheless, the content of this information remains mixed. Only the $16.6 \%$ of the sample has adopted the CESR/CO.N.SO.B. scheme. The rest of the sample departs from the Italian Stock Exchange disclosure model either by limiting the information to the Net Current Financial Indebtedness (1.7 percent) or by adding the non current financial assets to the CESR/CO.N.SO.B. computational scheme (72.4 percent).

The adoption of a mandatory disclosure regime has certainly increased the number of companies delivering information about their net indebtedness. However, the implementation of the CESR/CO.N.SO.B. rule has only slightly enhanced the comparability of the Italian listed companies' Net Debt disclosure, so stressing the role that market incentives - rather than regulators' activity - play in shaping companies' financial information. The subsequent multivariate analysis will detect some of the market forces that probably drive the content of the net debt disclosure.

\subsection{A Multivariate Analysis}

The descriptive analysis has stressed a weak compliance degree with regard to the CESR/CO.N.SO.B. rule and a high heterogeneity concerning the information about the net financial position. For this reason, this section develops a multivariate analysis on a sample of 159 firm-year observations from 2006 to 2008 in order to analyze factors affecting firms' choice to comply with CESR/CO.N.SO.B. rule.

To this end, the following binary logistic model is developed:

$$
\begin{aligned}
& \text { Compliance }=\alpha+\beta_{1} \text { CostOfDebt }+\beta_{2} \text { Leverage }+\beta_{3} \text { EbitdaCov }+\beta_{4} \text { Covenant }+ \\
& +\beta_{5} \text { Cov } * \text { Lev }+\beta_{6} \text { Cov * EbitdaCov }+\sum_{i=1}^{4} \gamma_{i} \text { FinancialV ariables }+ \\
& +\sum_{k=1}^{4} \lambda_{k} \text { Governance Variables }+\varphi_{1} \text { Industry }+\varphi_{2} \text { Year }+ \text { Error }+ \text { Term }
\end{aligned}
$$

The dependent variable "Compliance" equals 1 if the firm adopts the CESR/CO.N.SO.B. Net Debt disclosure scheme, and 0 otherwise. Then, in order to assess a possible misuse of the net debt disclosure, we analyze the relation between the variable "Compliance" and some financial ratios whose value depend on the firm's gearing level: Cost of Debt, Leverage and EbitdaCov. Moreover, a dummy variable "Covenant" has been introduced to assess the impact on the net debt disclosure of contractual arrangements between lenders and borrowers, while the interaction variables "Cov*Lev" and "Cov*EbitdaCov" measure how the existence of debt covenants affects firm $j$ 's compliance probability jointly with its gearing level and the magnitude of its Ebitda coverage.

Finally, before testing for variables that might directly affect the compliance degree of a firm, the regression 
model also controls for financial (Size, Price/Book, ROA, and IntCov) and corporate governance variables (BRD_Size, $\% I N D$, Dual and $\% O w n$ ) that are deemed to influence firm $j$ 's disclosure quality regardless of the gearing level.

To conclude, two dummy variables "Industry" and "Year" control for industry and year fixed effects.

Table 4 presents a brief description of the independent variables. Figure 1 shows the expected signs of the coefficients of the independent variables.

Table 4. Variables definition

\begin{tabular}{|c|c|}
\hline Variables & Definitions \\
\hline \multicolumn{2}{|c|}{ Dependent Variable } \\
\hline Compliance & $\begin{array}{l}\text { Dummy variable equal to } 1 \text { if firm } j \text { fully comply with CESR/Consob Net Debt disclosure scheme, and } 0 \\
\text { otherwise. }\end{array}$ \\
\hline \multicolumn{2}{|c|}{ Predictor Variables } \\
\hline CostOfDebt & Interest expenses to interest-bearing debts \\
\hline Leverage & Interest-bearing debts to total assets \\
\hline EbitdaCov & Ebitda to total interest-bearing debts \\
\hline Covenant & Dummy variable equal to 1 if firm $j$ 's disclose the existence of debt covenants, and 0 otherwise \\
\hline Cov*Lev & Interaction variable between the dummy variable Covenant and Leverage \\
\hline Cov*EbitdaCov & Interaction variable between the dummy variable Covenant and EbitdaCov \\
\hline \multicolumn{2}{|c|}{ Financial Control Variables } \\
\hline Size & $\log$ of firm $j$ 's total sales \\
\hline Price/Book & Market value of equity to the book value of equity \\
\hline ROA & Firm $j$ 's return on assets \\
\hline IntCov & Firm $j$ 's ratio of Operating Income to interest expenses \\
\hline \multicolumn{2}{|c|}{ Corporate Governance Control Variables } \\
\hline BRD_Size & Total number of board members \\
\hline$\% \mathrm{IND}$ & Number of outside independent directors to total number of directors \\
\hline Dual & Dummy variable equal to 1 if the chairman is also an executive of the company and 0 otherwise \\
\hline$\%$ Ownership & Percentage of the share capital owned by shareholders who possess more than $2 \%$ of the share capital \\
\hline Industry & Industry dummies \\
\hline Year & Year dummies \\
\hline
\end{tabular}




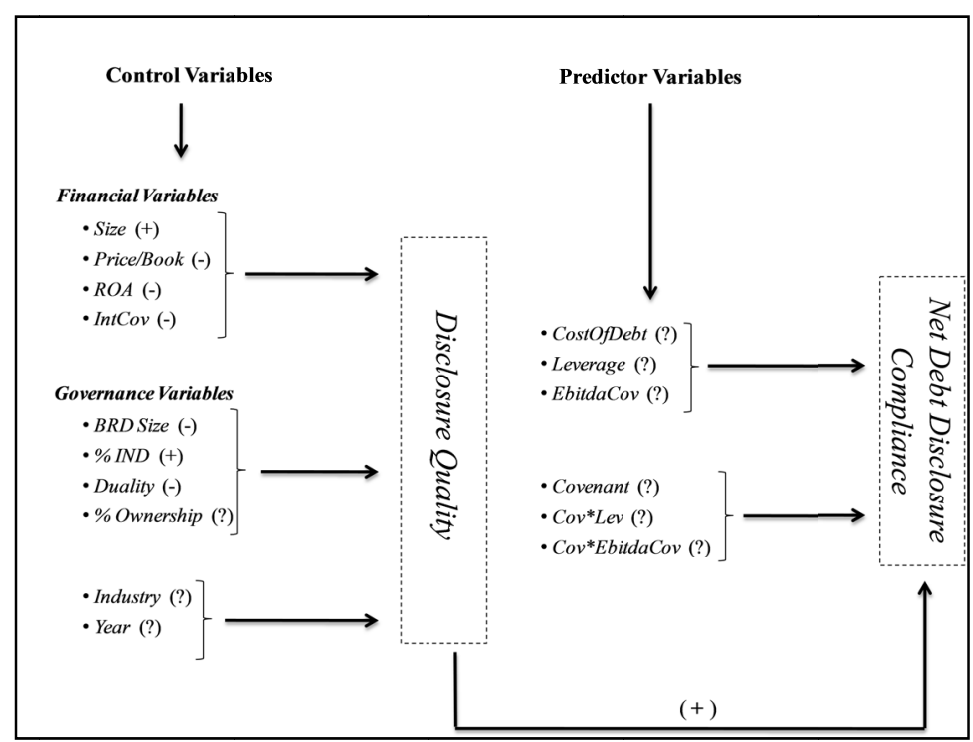

Figure 1. Expected relations between independent variables and the net debt disclosure compliance (Note 5)

Before running the regression model, we isolate the outlying observations by means of the three-sigma (standard deviation) rule (Barnett, Lewis, 1994):

$$
|x-\mu(x)| \geq 3 \sigma(x)
$$

Consequently, the number of observations decreases to 159 . Table 5 summarizes their descriptive statistics after excluding the outliers.

Table 5. Descriptive statistics

\begin{tabular}{lccccc}
\hline Independend Variables & MIN & MAX & Median & Mean & Standard Dev. \\
\hline CostOfDebt & .0051 & .2000 & .0508 & .0579 & .0316 \\
Leverage & .0000 & .7066 & .1963 & .2210 & .1644 \\
EbitdaCov & -5.040 & 7.590 & .8293 & 1.049 & 1.400 \\
Covenant & Included & - & - & - & - \\
Cov*Lev & Included & - & - & - & - \\
Cov*EbitdaCov & Included & - & - & - & - \\
Size & 4.010 & 11.760 & 6.532 & 7.011 & 1.779 \\
Price/Book & .2200 & 6.157 & 1.652 & 1.791 & 1.156 \\
ROA & -.1900 & .2500 & .0547 & .0504 & .0814 \\
IntCov & -41.380 & 79.090 & 3.202 & 4.967 & 11.304 \\
BRD_Size & 5 & 17 & 10 & 10.264 & 3.013 \\
\%IND & .0000 & .8300 & .3600 & .4027 & .1999 \\
Dual & Included & - & - & - & - \\
\%Own & .2388 & .8849 & .6540 & .6298 & .1613 \\
Industry & Included & - & - & - & - \\
Year & Included & - & - & - & - \\
& & & & & \\
\hline
\end{tabular}

We also check for multicollinearity through a univariate correlation matrix (Table n. 6). All the correlation values are below the critical limit of 0.80 , suggesting that a multicollinearity problem between independent variables is not a serious concern (Hair et al., 1995). 
Table 6. Pearson correlation among selected variables

\begin{tabular}{|c|c|c|c|c|c|c|c|c|c|c|c|c|c|c|}
\hline & 1 & 2 & 3 & 4 & 5 & 6 & 7 & 8 & 9 & 10 & 11 & 12 & 13 & 14 \\
\hline 1. CostOfDebt & 1 & & & & & & & & & & & & & \\
\hline 2. Leverage & -.106 & 1 & & & & & & & & & & & & \\
\hline 3. EbitdaCov & .073 & -.003 & 1 & & & & & & & & & & & \\
\hline 4. Covenant & -.004 & $.348^{* *}$ & -.026 & 1 & & & & & & & & & & \\
\hline 5. $\mathrm{Cov}^{*} \mathrm{Lev}$ & -.023 & .687 ** & -.095 & $.790 * *$ & 1 & & & & & & & & & \\
\hline 6. $\mathrm{Cov}^{*}$ EbitdaCov & -.015 & .065 & $.432 * *$ & $.554^{* *}$ & $.321 * *$ & 1 & & & & & & & & \\
\hline 7. Size & .133 & $.270 * *$ & -102 & -.092 & -.048 & .068 & 1 & & & & & & & \\
\hline 8. Price/Book & -.107 & $.170 *$ & $.188 *$ & .004 & .131 & .135 & .075 & 1 & & & & & & \\
\hline 9. ROA & $.159^{*}$ & -.076 & $.406 * *$ & .004 & -108 & $.219^{* *}$ & $.322 * *$ & $.190 *$ & 1 & & & & & \\
\hline 10. IntCov & -.114 & $-.193 *$ & $.647 * *$ & -.040 & -.095 & $.167^{*}$ & -.045 & $.167^{*}$ & $.435^{* *}$ & 1 & & & & \\
\hline 11. BRD_Size & -.084 & .129 & -.040 & .001 & .043 & .042 & $.345 * *$ & $.362 * *$ & -.001 & .011 & 1 & & & \\
\hline 12. $\% \mathrm{IND}$ & .088 & -.044 & -.057 & -.120 & $-.186 *$ & $-.159 *$ & $.312 * *$ & .048 & .110 & -.113 & 0.40 & 1 & & \\
\hline 13. Dual & $-203 *$ & .003 & .037 & .008 & .032 & .014 & -.035 & .008 & .032 & .147 & .052 & -.063 & 1 & \\
\hline 14. $\%$ Own & $-.282 * *$ & -.048 & -.152 & .098 & .127 & .054 & $-.387 * *$ & .075 & $-.174 *$ & -.005 & -.127 & $-.238 * *$ & .000 & 1 \\
\hline
\end{tabular}

Note. ${ }^{* *}$ Correlation is significant at the 0.01 level (two-tailed); * Correlation is significant at the 0.05 level (two-tailed)

Finally, the heteroskedasticity and autocorrelation problems associated to the clustered nature of the sample are mitigated by developing a clustered-robust standard errors regression (Wooldridge, 2001).

Table 7 reports the empirical results of the clustered-robust logistic regression analysis developed on 159 observations.

Table 7. Multivariate analysis

\begin{tabular}{|c|c|c|c|}
\hline Independent Variables & Coefficient & $\begin{array}{l}\text { Robust Standard } \\
\text { Error }\end{array}$ & $z$-statistic \\
\hline CostOfDebt & -47.097 & 16.001 & $-2.94 * * *$ \\
\hline Leverage & -40.873 & 9.647 & $-4.24 * * *$ \\
\hline EbitdaCov & 1.383 & .668 & $2.07 * *$ \\
\hline Covenant & 4.066 & 1.886 & $2.16 * *$ \\
\hline Cov*Lev & 39.478 & 10.862 & $3.63 * * *$ \\
\hline Cov*EbitdaCov & -1.653 & .837 & $-1.97 * *$ \\
\hline Size & .662 & .297 & $2.22 * *$ \\
\hline Price/Book & -.620 & .470 & -1.32 \\
\hline ROA & 10.788 & 5.828 & 1.85 \\
\hline IntCov & -.235 & .086 & $-2.74 * * *$ \\
\hline BRD_Size & .083 & 191 & .43 \\
\hline$\%$ IND & 6.281 & 2.536 & $2.48 * *$ \\
\hline Dual & -.634 & .918 & -.69 \\
\hline$\%$ Own & 11.518 & 3.656 & $3.15 * * *$ \\
\hline Industry Dummies & Included & - & - \\
\hline Year Dummies & Included & - & - \\
\hline Number of Observations & & & 159 \\
\hline Prob $>$ chi2 & & & .000 \\
\hline Pseudo-R2 & & & .508 \\
\hline Hosmer-Lemeshow chi2 & & & 6.29 \\
\hline Prob $>$ chi 2 & & & .615 \\
\hline
\end{tabular}

Note. ${ }^{* *}$ Correlation is significant at the 0.01 level (two-tailed); ** Correlation is significant at the 0.05 level (two-tailed). 
The pseudo $R$-square is equal to $50.8 \%$ and indicates that a great part of the variation in the dependent variable is due to changes in the explanatory ones. The Hosmer \& Lemeshow test also allows accepting the hypothesis that the model fits well ( $p$-value > 0.1) (Hosmer, Lemeshow, 1980; 2000).

As expected, the dependent variable shows a positive and significant relation with Size ( $p$-value $<0.05), \%$ IND $(p$-value $<0.05)$ and $\%$ Own $(p$-value $<0.01)$. The compliance probability is also negatively and significantly related with the control variable IntCov $(p$-value $<0.01)$.

An examination of the relationship between the compliance degree and the predictor variables shed lights on a significant correlation between the choice to deliver a full net debt disclosure and the magnitude of some long-term solvency ratios. In particular, the dependent variable is negatively correlated with CostOfDebt and Leverage ( $p$-value $<0.01$ ), while a positive relation has been detected between the Compliance variable and the Ebitda Coverage. The existence of debt covenants also seems to affect the compliance with the CESR/CO.N.SO.B. net debt rule. Indeed, the dependent variable is positively and significantly correlated to the dummy variable Covenant ( $p$-value $<0.05$ ) and to the interaction variable $\operatorname{Cov}^{*} \operatorname{Lev}(p$-value $<0.01)$. Finally, a negative and significant relationship is detected between Compliance and the interaction variable Ebitda*Cov $(p$-value $<0.05)$.

The results of the regression analysis partially show the opportunistic nature of net debt disclosure. In fact, the lower is the credit risk rating of the Italian listed companies the higher is their compliance degree with the net indebtedness CESR/CO.N.SO.B. rule. Our examination also stresses the effectiveness of lenders' monitoring activities as the existence of debt covenants increases the probability of the compliance degree, particularly when the gearing and the Ebitda Coverage ratios get worse. Finally, the multivariate evidence indirectly highlights the role played by the regulation as a low-cost commitment device. In fact, a positive relation between the dependent variable and the existence of debt covenants draws the attention to the fact that the CESR/CO.N.SO.B. Net debt configuration (rather than any other privately chosen computational schemes) is often adopted to regulate terms and conditions of debt contracts. Therefore, the standardization of the Net Debt disclosure appears also to be an efficient instrument to lower the costs associated to the debt bargaining process.

\section{Concluding Remarks and Limitations}

Notwithstanding the fundamental role played by the net financial position as a "performance indicator", the boundaries of this financial item have not been well designed yet and scholars and standard setters have proposed different interpretations.

In such a scenario, by ratifying a CESR Recommendation, in 2006 the CO.N.SO.B. has issued a new regulation aiming at increasing the quality of the net debt disclosure and enhancing the degree of comparability and understandability of Italian listed companies' financial statements. The implementation of the CO.N.SO.B. rule has created an ideal setting for: 1) comparing the content of the Net Debt disclosure produced in a non-regulated environment with that delivered within a mandatory disclosure regime; 2) assessing the ability of regulators' activity to prevent managers from offering a biased picture of their entity's liquidity and solvency positions; and 3) evaluating the possibility that a mandatory disclosure on Net Debt might serve as a low-cost commitment device enhancing the efficiency in debt contracting processes.

As to point 1), the descriptive analysis shows that the adoption of a mandatory disclosure regime has increased the number of companies delivering information about their net indebtedness. However, the implementation of the CESR/CO.N.SO.B. rule has only slightly enhanced the comparability of the Italian listed companies' Net Debt disclosure, highlighting the role that market incentives-rather than regulators' activities-play in shaping the content of the net indebtedness financial information.

With regards to points 2) and 3), the multivariate analysis shows the opportunistic nature of Net Debt disclosure and the effectiveness of lenders' monitoring activity. Finally, the multivariate evidence indirectly highlights the role played by the regulation as a low-cost commitment device. In fact, the standardization of the Net Debt disclosure appears to be an effective instrument to lower the debt bargaining costs as the presence of debt covenants significantly increases the probability to comply to the CO.N.SO.B. rule.

This study is subject to some limitations. The CO.N.SO.B. intervention in 2006 made the Italian setting an ideal one to examine the impact of the introduction of a narrow/regulated approach concerning the notion of- and the disclosure about Net Debt. However, the results we collect in terms of variables affecting the actual compliance degree and a possible misuse of Net Debt disclosure are inevitably influenced by the specificity of the Italian institutional context. Therefore, it is necessary to consider the effectiveness and the efficiency of corporate governance systems and enforcement mechanisms characterizing the Italian stock exchange before extending 
these results to different markets.

The multivariate analysis captures the compliance degree of the Italian listed companies by using a dichotomic variable (Compliance) which equals 1 if the firm adopts the CESR/CO.N.SO.B. Net Debt disclosure scheme, and 0 otherwise. Such a methodological approach ensures a high degree of verifiability and comparability between the observations, but it also offers a rough picture of Net Debt disclosure delivered by the Italian companies.

However, these limitations do not affect the contribution this paper can make. Rather, they demand further analysis to deepen our knowledge of a topic only partially explored and that still poses a major concern for regulators and overseers.

\section{References}

Abdel-Khalik A. R. (1981). The Economic Effects on Lessess of FASB Statement n. 13 Accounting for Leases. Stamford, CT: FASB.

Barnett, V., \& Lewis, T. (1994). Outliers in Statistical Data (3rd ed.), John Wiley \& Sons.

Beattie, V., Goodacre, A., \& Thomson, S. (2006). International Lease-Accounting Reform and Economic Consequences: The Views of UK Users and Preparers. International Journal of Accounting, 41, 75-103, http://dx.doi.org/10.1016/j.intacc.2005.12.003

Bhattacharyya, A. (2011). Essentials of Financial Accounting (2nd ed.). PHI Learning.

Coffee, J. C. (1984). Market Failure and the Economic Case for Mandatory Disclosure System. Virginia Law Review, 70, 717-753.

Commissione Nazionale per le Società e la Borsa (CO.N.SO.B.). (2006). Communication DEM/6064293, July.

Committee of European Securities Regulators (CESR). (2005). Recommendations for the Consistent Implementation of the European Commission's Regulation on Prospectuses $\mathrm{n}$.

Cooper, K., \& Keim, G. D. (1983). The Economic Rationale for the Nature and Extent of Corporate Financial Disclosure Regulation: A Critical Assessment. Journal of Accounting and Public Policy, 2(3), 189-205.

Corporate Reporting Users' Forum (CRUF). (2009). Letter of Comment n. 110A.

Damodaran, A. (2012). Investment Valuation: Tools and Techniques for Determining the Value of Any Assets. New York: John Wiley and Sons.

Demigurc-Kunt, A., \& Levine, R. (2001). Bank-Based \& Market-Based Financial Systems: Cross-Country Comparisons. In Financial Structure and Economic Growth: A Cross-Country Comparison of Banks, Markets, and Development, MIT Press, Cambridge, 81-140.

Diamond, D., \& Verrecchia, R. (1991). Disclosure, Liquidity, and the Cost of Capital. The Journal of Finance, $66,1325-1355$.

Dichev, I., \& Skinner, D. (2002). Large-Sample Evidence on the Debt Covenant Hypothesis. Journal of Accounting Research, 40, 1091-1123.

Elliot, T., \& Elliot, J. (1997). Financial Accounting and Reporting. Prentice Hall.

Engel, E., Erickson, M., \& Maydew, E. (1999). Debt-Equity Hybrid Securities. Journal of Accounting Research, 37, 249-274.

Godfrey, J. M., \& Warren, S. M. (1995). Lessee Reactions to Regulation of Accounting for Leases. Abacus, 31, 201-228.

Gonedes, N. J., \& Dopouch, N. (1974). Capital Market Equilibrium, Information Production, and Selected Accounting Techniques: Theoretical Framework and Review of Empirical Work. Studies on Financial Accounting Objectives, (Supplement to Journal of Accounting Research), 48-129.

Gordon, J. N. (1989). The Mandatory Structure of Corporate Law. Columbia Law Review, 89, 1549-1598.

Hair, J. F., Anderson, R. E., Tatham, L., \& Black, W. C. (1995). Multivariate Data Analysis (4th ed.). Prentice-Hall.

Hosmer, D. W., \& Lemeshow, S. (1980). Goodness of Fit Tests for Multiple Logistic Regression Model. Communication in Statistics: Theory and Methods, 9, 1043-1069. http://dx.doi.org/10.1080/03610928008827941

Hosmer, D. W., \& Lemeshow, S. (2000). Applied Logistic Regression (2nd ed.). New York: Wiley. 
Kim, O., \& Verrecchia, R. (1994). Market Liquidity and Volume Around Earnings Announcements. Journal of Accounting and Economics, 17, 41-68. http://dx.doi.org/10.1016/0165-4101(94)90004-3

KPMG (2010). New on the Horizon: Financial Statement Presentation. Retrieved from http:// www.in.kpmg.com

Lambert, R., Leuz, C., \& Verrecchia, R. (2007). Accounting Information, Disclosure, and the Cost of Capital. Journal of Accounting Research, 45, 385-420. http://dx.doi.org/10.1111/j.1475-679X.2007.00238.x

Leuz, C., \& Verrecchia, R. (2000). The Economic Consequences of Increased Disclosure. Journal of Accounting Research, 38, 91-124.

Leuz, C., \& Wysocki, P. (2008). Economic Consequences of Financial Reporting and Disclosure Regulation: A Review and Suggestions for Future Research. Working Paper.

Mahoney, P. (1995). Mandatory Disclosure as a Solution to Agency Problems. The University of Chicago Law Review, 62, 1047-1112.

May, R. G., \& Sundem, G. L. (1976). Research for Accounting Policy: An Overview. The Accounting Review, 747-763.

Mork, R., Shleifer, A., Vishny, W. (1988). Management Ownership and Market Valuation: An Empirical Analysis. Journal of Financial Economics.

Palepu, K. G., \& Healy, P. M. (2008). Business Analysis \& Valuation: Using Financial Statements (4th ed.). Thomson.

Penman, S. H. (2007). Financial Statement Analysis and Security Valuation (3rd ed.). Mc-Graw Hill.

Pizzo M. (2010). La Posizione Finanziaria Netta nella Dottrina e nella Prassi Contabile: brevi note. In Scritti in Onore di Vittorio Coda, Egea, Milano.

Rock, E. (2002). Securities Regulation as Lobster Trap: A Credible Commitment Theory of Mandatory Disclosure. Cardozo Law Review, 23, 675-704.

Sengupta, P. (1998). Corporate Disclosure Quality and the Cost of Debt. The Accounting Review, 73, 459-474.

Subramanyam, K. R., \& Wild, J. J. (2009). Financial Statement Analysis. New York: McGraw-Hill International Edition.

Sweeney, A. P. (1994). Debt-Covenant Violations and managers accounting responses. Journal of Accounting and Economics, 17, 281-308.

Teodori, C. (2009). Il Rendiconto Finanziario: Caratteristiche, Ruolo Informativo ed Interpretazione. Giappichelli, Torino.

Vernimmen, P., Quiry, P., Dallocchio, M., Le Fur, Y., \& Salvi, A. (2011). Corporate Finance Theory: Theory and Practice (3rd ed.). John Wiley \& Sons.

Wooldridge, J. M. (2001). Econometric Analysis of Cross Section and Panel Data. Cambridge, Massachusetts: The MIT Press.

\section{Notes}

Note 1. On 1 January 2011, the CESR has been replace by the European Securities and Markets Authority (ESMA).

Note 2. In this case, the Net Debt is defined as «Net Current Financial Indebtedness» + «Non Current Financial Indebtedness». The first addendum is given by Liquidity + Current Financial Receivables + Current Financial Debt. The second addendum is the sum of Non-Current Bank Loans, Bonds Issued and Other Non-Current Loans.

Note 3. International Accounting Standard Board, Staff Draft of Exposure Draft, Financial Statement Presentation, 2010.

Note 4. "The FASB does not support requiring disclosure of net debt information [...] because there is a variety of ways to calculate net debt and it is relatively easy for users to obtain the information used in net debt calculations. Furthermore [...] disclosure of net debt information could be misleading because it might give the impression that an entity has allocated its capital to the settlement of its debt, which might not be the case." FASB, Staff Draft, BC217, 2010. 
Note 5. A potential non-monotonic relationship between \%Own and firm's corporate governance strength does not allow to reasonably predict the sign of the correlation between Compliance and \%Own (Mork et al., 1988).

\section{Copyrights}

Copyright for this article is retained by the author(s), with first publication rights granted to the journal.

This is an open-access article distributed under the terms and conditions of the Creative Commons Attribution license (http://creativecommons.org/licenses/by/3.0/). 